\title{
Ground water quality evaluation with special reference to nitrate pollution in the Sangamner area, Ahmednagar district, Maharashtra, India
}

\author{
K. K. Deshmukh \\ Post-Graduate Research Center in Chemistry, \\ Sangamner Nagarpalika Arts, D.J. Malpani Commerce and B.N. Sarda \\ Science College, Sangamner, Dist. Ahmednagar, (M.S.), India
}

\begin{abstract}
Water is an essential natural resource for sustaining life and environment which we have always thought to be available in abundance and a free gift of nature. Though groundwater is the major drinking water source, deterioration in its quality is questionable. In recent years, pollution by nitrate leaching from agricultural land has become an important concern. The notable toxic effect of nitrate is infant methaglobinema. The symptoms of nitrate poisoning are also well recognized in animals. In agro-economy based rural areas, the nitrate contamination is rampant and much attention has not been drawn towards this anthropogenic pollution. In the study area, 68 ground water samples from different hydro geological set up have been collected during pre and post monsoon seasons and analyzed for $\mathrm{pH}, \mathrm{EC}$ and major ions such as $\mathrm{Ca}^{2+}, \mathrm{Mg}^{2+}$, $\mathrm{Na}^{+}, \mathrm{K}^{+}, \mathrm{CO}_{3}{ }^{2-}, \mathrm{HCO}_{3}{ }^{-}, \mathrm{CI}^{-}, \mathrm{SO}_{4}{ }^{2-}$ and $\mathrm{NO}_{3}{ }^{-}$. The study revealed that the majority of the samples from irrigated agriculture have $\mathrm{NO}_{3}>45 \mathrm{mg} / \mathrm{l}$. The groundwater found to be unsuitable for drinking purposes. Intensive agriculture practices, excess use of nitrogeneous fertilizers, improper organic waste disposal, monoculture type of cropping pattern, mixing of sugar mill effluents are the possible causes of high concentration of nitrate in the groundwater. The $\mathrm{Cl}^{-} / \mathrm{NO}_{3}{ }^{-}$ ratio for the groundwater from irrigated land use is $<2$ indicating fertilizers as the predominant source of nitrate. High values of nitrate in wells with deeper water table indicate cessation of denitrification processes at greater depth. Lower values of nitrate in the wells with shallow water table depth have been attributed to denitrification process. On the temporal scale, the nitrate decreases in winter and increases in summer. This is possibly attributed to concentration-dilution
\end{abstract}


effect. The present study is helpful in avoiding the hazards of nitrate contamination and avoids major health problems in the area. Undertaking investigation in such areas would thus reduce the cost of studies and in implementing groundwater quality management programs to avoid the hazards of contamination.

Keywords: groundwater evaluation, nitrate pollution, nitrogeneous fertilizers, methemoglobinemia, denitrification, domestic purpose.

\section{Introduction}

Water is essential natural resource for sustaining life and environment which we have always thought to be available in abundance and free gift of nature. Groundwater forms a major source of drinking water in urban as well as in rural areas. Groundwater has the properties of dissolving and carrying in solution, a variety of chemicals and other materials. More than $90 \%$ of the rural population uses groundwater for domestic purposes. Major problems are being faced by the country due to the presence of excess fluoride, arsenic and nitrate in groundwater in certain parts of country [1].

In recent years, pollution by nitrate leaching from agricultural land has become an important concern. This is because of its potential pollution of surface and groundwater. The nitrate pollution includes spreading of nitrogenous fertilizers, mis-management of irrigated crops and disposal of livestock waste and cultivation of virgin land [2]. However, nitrate pollution problem is more aggravated especially in regions where large doses of agricultural fertilizers are applied. It is to be noted that nitrate themselves are not especially dangerous. But when certain bacteria are present in the digestive tract may convert the nitrates into highly toxic nitrites. In turn, nitrate can lead to 'blue baby Syndrome' (methemoglobinemia), which can be fatal to infants during the first three months of life [3]. Presence of nitrates poses some unique problems to groundwater threat because of its specific characteristic properties like high solubility, moves quickly through the soils with percolating water, often indicates potential biological contamination and part of it is removed by roots of growing plants and converts to gas or bacteria. The groundwater resources contaminated with high levels of nitrate $\left(>45 \mathrm{mg} / \mathrm{l}\right.$ as $\mathrm{NO}_{3}$ or $10 \mathrm{mg} / \mathrm{l}$ as $\left.\mathrm{NO}_{3}-\mathrm{N}\right)$ are an environmental hazard. Incidences of nitrate pollution of groundwater have been reported by several workers [4-11]. Sangamner area is experiencing the interplay between natural and human induced factors. These factors in combination have lead to degradation of overall soil and groundwater environment. Therefore, it is essential to evaluate groundwater quality with reference to nitrate pollution status in the study area.

\section{Study area}

Sangamner area is located in the northern part of the Ahmednagar district of Maharashtra State, India. The tahsil lies between $18^{\circ} 36^{\prime} \mathrm{N}$ to $19^{\circ} 1^{\prime} \mathrm{N}$ latitude and $74^{\circ} 1^{\prime} \mathrm{W}$ to $74^{\circ} 56^{\prime} \mathrm{W}$ longitude. The Sangamner town is located on the 
confluence of the Mahalungi and the Pravara river. It is a Taluka head quarter which is at a distance of $150 \mathrm{~km}$ from Pune, on Pune-Nasik National Highway No. NH-50 (Fig. 1).

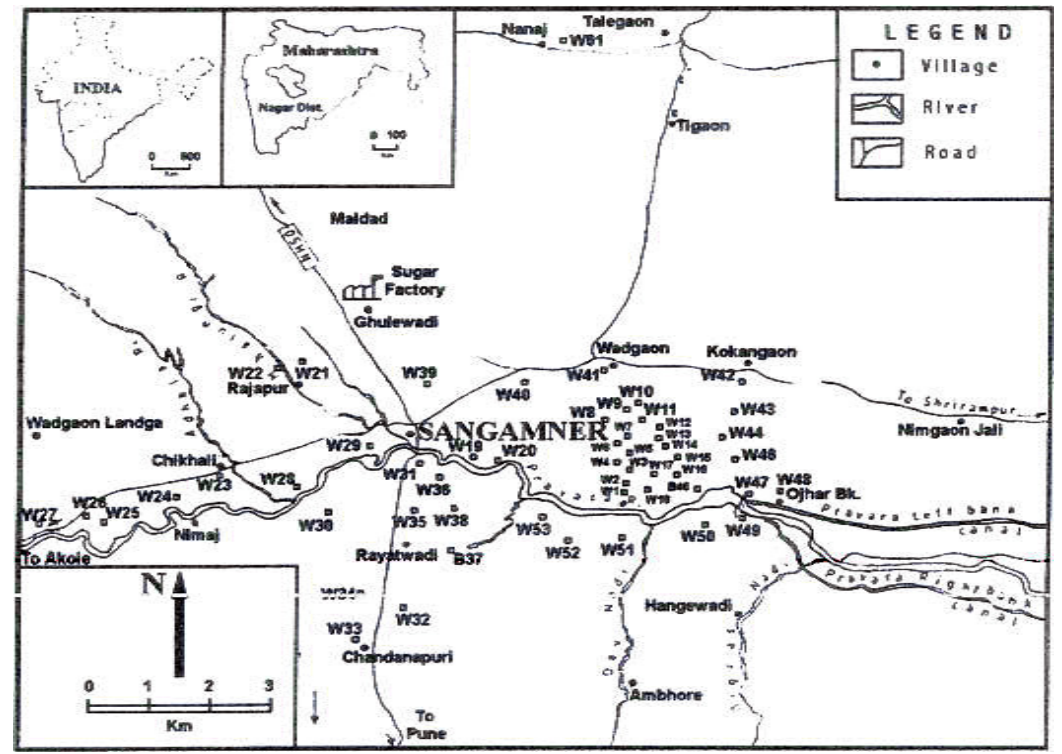

Figure 1: Locations of ground water sampling stations in the study area.

The area is drained by the Pravara River which is a tributary of Godavari and has its origin in the hilly region of Western Ghats. Geologically, basalt underlay the Pravara basin, which is characterized by thick alluvium (up to $35 \mathrm{~m}$.). Several dams and weirs have been constructed across Pravara River. Because of construction of Bhandardara dam in the source region of Pravara River, the valley has been brought under intensive agriculture with sugarcane as a single dominant crop. Subsequent to the establishment of co-operative sugar mill at Sangamner in 1967, the agriculture in the area has witnessed rapid changes in the cropping pattern. In addition to sugar industry several allied industrial units have also come up in the area. The effluents from sugar industry, with little or no treatment have been stored in lagoons and then discharged into the natural stream flowing through the agricultural area for a distance of about 8 to $9 \mathrm{~km}$. This effluent stream finally meets the Pravara River at Sangamner. While flowing through the natural stream, the effluent infiltrates through the soil zone into the nearby dug/bore wells thereby adversely affecting natural groundwater quality.

\section{Materials and methods}

A network of 68 groundwater-sampling stations spread over two seasons was established in the study area to monitor the chemical changes in the properties of 
groundwater. The 54 of them were from irrigated area and 14 from non-irrigated area. Sampling locations were chosen on the basis of pilot geological and hydrogeological survey of the area. During the survey information concerning land use, type of crops, amount of fertilizer used, the water quantity, source of water used for irrigation and frequency of application of water was collected. The samples from dug/bore wells were collected on the basis of its use for irrigation as well as for drinking purposes. The samples were collected in polyethylene bottles of one-liter capacity. The care was taken to collect samples after pumping for some time. The $\mathrm{pH}$, electrical conductivity (EC) and temperature were measured in the field. The samples were then brought to the laboratory for further chemical analysis. The samples were collected over two seasons i.e. post monsoon, December and pre monsoon, June. The analysis was carried out in the laboratory by using the procedures given by APHA, AWWA, WPCF [12]. Using titrimetric methods performed the analysis of chloride $\left(\mathrm{Cl}^{-}\right)$, total alkalinity as $\mathrm{CaCO}_{3}$, calcium $\left(\mathrm{Ca}^{2+}\right)$ and magnesium $\left(\mathrm{Mg}^{2+}\right)$. While nitrate and sulphate were analyzed by spectrophotometric methods (Hitachi-2000, UV-visible spectrophotometer), the alkali elements like sodium and potassium were detected by flame photometer (Corning 400). Using Stiff Computer program for calculating the charge balance error (CBE) was calculated to check the analytical accuracy. The charge balance error up to $10 \%$ was considered valid.

\section{Results and discussion}

\subsection{Groundwater quality evaluation for domestic purposes}

The physico-chemical analysis of 68 groundwater samples from the study area was done for post (December 2009) and pre (June 2010) monsoon. The summary of physico- chemicals characteristics of these samples is represented in Table 1.

Table 1: $\quad$ Summary of physico-chemical characteristics of groundwater from Sangamner area district Ahmednagar, Maharashtra, India.

\begin{tabular}{|c|c|c|c|c|c|c|}
\hline \multicolumn{4}{|c|}{ Post monsoon (Winter-December) } & \multicolumn{3}{|c|}{$\begin{array}{c}\text { Pre monsoon (Summer - } \\
\text { June) }\end{array}$} \\
\hline Parameter & Min & Max & Average & Min & Max & Average \\
\hline $\mathrm{P}^{\mathrm{H}}$ & 7.4 & 8.6 & 8.02 & 7.9 & 8.9 & 8.4 \\
\hline $\mathrm{EC} \mu \mathrm{S} / \mathrm{cm}$ & 360 & 10360 & 4026.5 & 513 & 11.1 & 4283 \\
\hline TDS ppm & 230 & 6734 & 2684 & 333 & 7215 & 2784 \\
\hline Na ppm & 16.4 & 380 & 161 & 7 & 492 & 341 \\
\hline $\mathrm{K} p p m$ & 0.1 & 3.4 & 1.26 & 0.2 & 18.3 & 0.8 \\
\hline Ca ppm & 13 & 172 & 45.5 & 36 & 485 & 188 \\
\hline $\mathrm{Mg} \mathrm{ppm}$ & 6.82 & 145 & 49.6 & 7 & 468 & 167 \\
\hline TH ppm & 62 & 904 & 317 & 200 & 2920 & 1190 \\
\hline $\mathrm{Cl} \mathrm{ppm}$ & 9 & 598 & 161 & 49 & 1510 & 511 \\
\hline $\mathrm{HCO}_{3} \mathrm{ppm}$ & 80 & 754 & 401 & 135 & 722 & 441 \\
\hline $\mathrm{SO}_{4} \mathrm{ppm}$ & 37.54 & 170 & 128 & 17 & 151 & 97 \\
\hline $\mathrm{NO}_{3} \mathrm{ppm}$ & 0.6 & 89 & 42.11 & 0 & 81 & 44.54 \\
\hline
\end{tabular}


The quality of groundwater in Sangamner area was studied with a view to evaluate the suitability of this groundwater for domestic purposes.

\subsubsection{Temporal variations in $\mathrm{pH}, \mathrm{EC}$ and Total Dissolved Solids (TDS)}

The analytical data revealed that the groundwater in the study area with $\mathrm{pH}$ values ranging from 7.9 to 8.9 with an average of 8.4 during pre monsoon and from 7.4 to 8.6 with an average of 8.02 during post monsoon season indicating alkaline nature representing the buffering capacity of water and its ability to resist a change in $\mathrm{pH}$. Lowering of $\mathrm{pH}$ in winter might be due to the introduction of $\mathrm{CO}_{2}$ from soil in winter zone during monsoon as the water table rises. In contrast, slight increase in $\mathrm{pH}$ in summer can be attributed to the large amount of bicarbonates in the ground water and discontinued supply of $\mathrm{CO}_{2}$ due to cessation of rain-fed recharge to the aquifer. This increase in $\mathrm{pH}$ can also be related to higher ionic content of water in this season. It is seen that $\mathrm{EC}$ values are lower $(4026 \mu \mathrm{S} / \mathrm{cm})$ in winter than in summer $(4283 \mu \mathrm{S} / \mathrm{cm})$. Lowering of EC values in winter could be due to dilution effect caused by rain-fed recharge during the monsoon season leading to higher ground water levels. The higher values during summer reflect concentration effect. This suggest that the control of evaporation on the hydrochemical diversity in the area. Increase in EC in summer confirms the inference drawn about higher $\mathrm{pH}$ values in this season. The TDS ranges from 333 to $7215 \mathrm{mg} / 1$ for pre monsoon while it varies from 230 to $6734 \mathrm{mg} / \mathrm{l}$ in post monsoon. The TDS of ground water sample in the pre monsoon season is found to be higher as compared to the TDS of the post monsoon season. Increase in TDS in pre monsoon confirms the interference drawn about higher EC values in this season. It is observed that $67.64 \%$ in pre monsoon and $72.05 \%$ in post monsoon samples have exceeded maximum permissible limit (Table 2) prescribed by the drinking water standard [13].

Table 2: Critical parameters exceeding the permissible limit in the study area.

\begin{tabular}{|l|c|c|c|c|}
\hline \multicolumn{1}{|c|}{ Parameter } & \multicolumn{2}{|c|}{$\begin{array}{c}\text { Indian Standard drinking } \\
\text { water - specification IS } \\
10500-1991 \text { (Reaffirmed } \\
\text { 2009) }\end{array}$} & $\begin{array}{c}\text { Sample } \\
\text { exceeding } \\
\text { permissible } \\
\text { limit in pre } \\
\text { monsoon }\end{array}$ & $\begin{array}{c}\text { Sample } \\
\text { exceeding } \\
\text { permissible } \\
\text { limit in post } \\
\text { monsoon }\end{array}$ \\
\cline { 2 - 6 } & $\begin{array}{c}\text { Desirable } \\
\text { Limit }\end{array}$ & $\begin{array}{c}\text { Permissible } \\
\text { Limit }\end{array}$ & $\%$ & $\%$ \\
\hline $\mathrm{pH}$ & 6.5 to 8.5 & No relaxation & $32(47.05)$ & $4(5.88)$ \\
\hline $\mathrm{TDS}, \mathrm{mg} / \mathrm{L}$ & 500 & 2000 & $46(67.64)$ & $49(72.05)$ \\
\hline $\mathrm{Ca}, \mathrm{mg} / \mathrm{L}$ & 75 & 200 & $31(45.58)$ & Nil \\
\hline $\mathrm{Mg}, \mathrm{mg} / \mathrm{L}$ & 30 & 100 & $44(64.70)$ & $9(13.23)$ \\
\hline $\mathrm{Cl}, \mathrm{mg} / \mathrm{L}$ & 250 & 1000 & $9(13.23)$ & Nil \\
\hline $\mathrm{SO}_{4}, \mathrm{mg} / \mathrm{L}$ & 200 & 400 & $\mathrm{Nil}$ & $\mathrm{Nil}$ \\
\hline $\mathrm{NO}_{3, \mathrm{mg} / \mathrm{L}}$ & 45 & No relaxation & $33(48.52)$ & $32(47.05)$ \\
\hline $\begin{array}{l}\mathrm{TH},(\mathrm{as} \mathrm{CaCO} \\
\mathrm{mg} / \mathrm{L}\end{array}$ & 300 & 600 & $49(72.05)$ & $9(13.23)$ \\
\hline
\end{tabular}




\subsubsection{Temporal variations in cationic constituents}

$\mathrm{Ca}^{2+}, \mathrm{Mg}^{2+}, \mathrm{Na}^{+}$and $\mathrm{K}^{+}$are the four important cations present in groundwater. Calcium concentration in the groundwater varies from 36 to $485 \mathrm{mg} / \mathrm{l}$ and 13 to $172 \mathrm{mg} / \mathrm{l}$ during pre and post monsoon respectively. Calcium is found to be higher during pre monsoon than in post monsoon season. It is found from the Table 2, 45.58\% samples in pre monsoon have exceeded the permissible limit specified by drinking water standard [13] and WHO [14]. Therefore, constant use of these well waters for drinking purpose may lead to kidney stones or joints pains in population. The Magnesium value varies from 7 to $468 \mathrm{mg} / 1$ and 6.82 to $145 \mathrm{mg} / \mathrm{l}$ during pre and post monsoon respectively. It is observed that $64.70 \%$ and $13.23 \%$ samples in pre and post monsoon respectively have exceeded the maximum permissible limit (Table 2) prescribed by drinking water standard [13]. Excess of calcium and magnesium shows the hardness in water and is not good for drinking purpose. Although magnesium has been called one of the most important electrolytes in the body and may be connected to lower occurrence of osteoporosis, high concentrations of magnesium can cause diarrhea and it has a high solubility and is geologically abundant [15]. The sodium content of the groundwater ranges from 7 to $492 \mathrm{mg} / \mathrm{l}$ in pre monsoon season and 16.4 to $380 \mathrm{mg} / \mathrm{l}$ in post monsoon season. WHO (1979) has given the guideline value for sodium as $200 \mathrm{mg} / \mathrm{l}$. It is observed that $27.94 \%$ and $38.23 \%$ samples in pre and post monsoon have exceeded the permissible limit. Sodium imbalance in drinking water has been reported to cause a large number of lives threatening diseases. Hence, the excess consumption of sodium has been recognized as risk factor in hypertension. The potassium concentrations are negligible although slight increase is noticed in post monsoon season. The maximum permissible limit of total hardness for drinking water is specified as $600 \mathrm{mg} / \mathrm{l}$ (Drinking water standard [13]). The Total Hardness values ranges from 200 to $2920 \mathrm{mg} / 1$ and 62 to $904 \mathrm{mg} / \mathrm{l}$ during pre and post monsoon respectively. Variation of hardness is more in post monsoon samples as compared to pre monsoon season due to leaching of calcium and magnesium bicarbonate through recharge. The study shows that $72.45 \%$ and $13.23 \%$ samples in pre monsoon and post monsoon respectively have exceeded maximum permissible limit (Table 2) prescribed by drinking water standard [13]. Therefore, it is found in the study area that majority of the samples in the downstream part of the irrigated area have exceeded the permissible limit of total hardness. Hence, groundwater from this area is not suitable for drinking purpose.

\subsubsection{Temporal variations in anionic constituents}

The anions in the groundwater include $\mathrm{HCO}_{3}{ }^{-}, \mathrm{Cl}^{-}, \mathrm{SO}_{4}{ }^{2-}$ and $\mathrm{NO}_{3}{ }^{-}$. The $\mathrm{Cl}^{-}$value ranges from 49 to $1510 \mathrm{mg} / \mathrm{l}$ and 9 to $598 \mathrm{mg} / \mathrm{l}$ during pre and post monsoon respectively. Very few samples have crossed the maximum permissible limit (Table 2) prescribed by drinking water standard [13]. The $\mathrm{SO}_{4}{ }^{2-}$ content of the groundwater ranges from 17 to $151 \mathrm{mg} / \mathrm{l}$ in pre monsoon and in the post monsoon it varies from 37 to $170 \mathrm{mg} / \mathrm{l}$. Sulphate is higher in post monsoon season may be due to action of leaching and anthropogenic activities. Sulphate is not active in summer season because it is mainly derived from fertilizer sources 
and farmers do not generally use fertilizers in summer. The entire samples in the study area are within the maximum permissible limit specified by drinking water standard [13] and WHO [14]. Higher concentration of sulphate in water can cause malfunctioning of the alimentary canal and shows cathartic effect on human body [16]. Excess sulphate problem does not exist in the area. In the present study, bicarbonate $\left(\mathrm{HCO}_{3}{ }^{-}\right)$value ranges from 135 to $722 \mathrm{mg} / \mathrm{l}$ and 80 to $754 \mathrm{mg} / \mathrm{l}$ during pre and post monsoon respectively. $\mathrm{HCO}_{3}{ }^{-}$was higher during post monsoon season may be due to action of $\mathrm{CO}_{2}$ upon the basic material of soil and rock since the origin of $\mathrm{HCO}_{3}{ }^{-}$can be related to the aquifer lithology.

\subsection{Nitrate pollution and human health}

Protection of groundwater from nitrate contamination is an often-overlooked health concern. Nitrates in drinking water is associated with a number of health problems such as gastrointestinal cancers, methemoglobinemia, Alzheimer's disease, vascular dementia, multiple sclerosis in human beings [17, 18]. Nitrate contamination leads to eutrophication of water bodies. In the context of facing the challenge of increasing food production from decreasing cultivable land, issues concerned with nitrate pollution in this country can be reviewed and policy options available for combating the problem can be studied. In the present study it is found that nitrate concentrations are higher in pre monsoon than in post monsoon (Table 1). In the study area, 33 samples (48.52\%) and 32 samples $(47.05 \%)$ in pre monsoon and post monsoon respectively have exceeded the permissible limit of nitrate $(>45 \mathrm{mg} / \mathrm{l})$ drinking water standard [13]. The high values of nitrate are observed in the irrigated area which can be attributed to excessive use of chemical fertilizers in the sugarcane-cultivating tract. The groundwater from the villages like Kanoli, Manoli, Rahimpur and Jorve have high concentrations of nitrate (Fig 1). It is also significant to note that area which is thickly populated with residential colonies and industrial sector have high nitrate concentration. The groundwater sample near the Sangamner town as well as sugar factory region have elevated concentration of nitrate.

It is further observed that in the intensive irrigation areas, excess use of nitrogenous fertilizers has hastened the process of nitrate built up. Around sugar factory areas mixing of effluents with groundwater is responsible for high order of nitrate values. It is also observed that nitrate pollution is localized to certain areas in the rural belt. This is attributed to the nitrogen excreted by cattle in the farm and dairies where large number of buffaloes and cows are housed in relatively small areas. In some villages during summer, it is a common practice to allow cattle herds swimming in the ponds or washed near wells. Excreta of these animals get accumulated and are leached by rainfall causing higher nitrate pollutions of waters. The extent of such groundwater pollution depends on bio gradation and soil and rock strata characteristics through which percolation takes place. 


\subsection{Contribution of land use in nitrate pollution}

The nitrate concentrations of two different land use types from the area indicate that the values are higher under sugarcane cultivation (S. No. W31, W35, W41, W43, W44, W53, etc). The calculations of $\mathrm{Cl}^{-} / \mathrm{NO}_{3}{ }^{-}$reflected the wide variations in ratio from irrigated and non-irrigated area. This is attributable to various factors such as variation in fertilizer nitrogen loss due to denitrification, removal of more nitrogen than chloride by the harvested crops, change in the rate of nitrogen fertilizer application, land uses affecting adjacent shallow wells, requirement of crops for fertilizer utilization and contamination of non-point sources $[7,8]$. However, it is observed that $\mathrm{Cl}^{-} / \mathrm{NO}_{3}{ }^{-}$ratio is somewhat higher in the downstream part of the river (S. No. W1 to W16). This is possibly attributed to water logging associated with saline groundwater. That is to say that the concentration of chloride is higher in saline groundwater while nitrate losses due to denitrification. The upstream part of irrigated area (S.No. W27) showed lower values of $\mathrm{Cl}^{-} / \mathrm{NO}_{3}{ }^{-}$suggesting fertilizer is the source of nitrate. It is, however, interesting to note that, in general, $\mathrm{Cl}^{-} / \mathrm{NO}_{3}^{-}$is low in winter than in summer. This is attributable to low concentration of chloride in winter due to dilution effect. While the nitrate concentration is not affected in proportion to chloride possibly due to the addition of fertilizers in winter. The $\mathrm{Cl}^{-} / \mathrm{NO}_{3}{ }^{-}$ratio is low for some of the samples (S. No. W17, W19, W21, W24, W31 and W33) at higher depth. As it is noted that the trend of nitrate is in increasing order with depth. Interestingly, most of the samples have been shown higher values of nitrate ( $>$ $45 \mathrm{mg} / \mathrm{l}$ ) coincide with lower value of $\mathrm{Cl}^{-} / \mathrm{NO}_{3}{ }^{-}$ratio (S. No. S33, S41 and S53) suggesting build up of nitrate in the groundwater.

In general, higher values of $\mathrm{Cl}^{-} / \mathrm{NO}_{3}{ }^{-}$obtained in the area for majority of the samples indicate more efficient removal of fertilizer and proper farm management practices. Isolated occurrence of high nitrate values are common in non-irrigated agriculture land use (S. No. W37 and W58). This is possibly indicating the combined effect of fertilizer and non-fertilizer sources of nitrate. Such wells are surrounded by sugarcane fields close to cattle waste disposal. Infiltration of fertilizer leachate has possibly affected the quality of groundwater in these wells. However, higher concentration of nitrate from irrigated land-use can be considered as an effect of agricultural practices.

\section{Conclusion}

Hydrogeochemical studies of Sangamner area, Ahmednagar District revealed that the concentrations of TDS, total hardness, $\mathrm{Na}^{+}, \mathrm{Ca}^{2+}, \mathrm{Mg}^{2+}$ and nitrate are exceeding the permissible limit in the majority of the samples particularly from irrigated area. The number of samples exceeding the standard limit is higher in summer than in winter season. This suggests that quality of groundwater from irrigated land use is almost unsatisfactory for domestic purposes. Groundwater quality is strongly influenced by bedrock geology and climate but may also be attributed to the impacts of agricultural pollution. The present water availability situation in the study area is under great threat. Majority of the samples from 
irrigated agriculture have $\mathrm{NO}_{3}>45 \mathrm{mg} / \mathrm{l}$. Intensive irrigation along with monoculture type of cropping pattern besides excess use of nitrogenous fertilizers are the possible causes of high concentration of nitrate in the groundwater. It is inferred that the excess use of urea possibly enriched nitrate content in the groundwater. The $\mathrm{Cl}^{-} / \mathrm{NO}_{3}{ }^{-}$ratio for the groundwater from the irrigated land use is $<2$ indicating fertilizers as the predominant source of nitrate. High values of nitrate in the wells with deeper water table indicate cessation of denitrification process at greater depth. Lower values of nitrate in the wells with shallow water table depth have been attributed to denitrification processes in the vadose zone. Regular monitoring of water quality is recommended to improve understanding of nitrate pollution in the groundwater in the Sangamner area and in surrounding region.

\section{References}

[1] Sunitha V, Reddy B.R., and Reddy M.R. Groundwater quality evaluation with special reference to fluoride and nitrate pollution in Uravakonda, Anantpur District, A.P, Int. J. Res. Chem Environ. 2 (1), pp. 88-96, 2012.

[2] Sehmi K., Suchet P.A., Clauser N. and Probst J. Impact of nitrogen fertilizer on the natural weathering erosion process and fluvial transport in the Garonne basin, Applied Geo Chemistry, 15, pp. 865-878, 2000.

[3] Mathur P. and Tomer P., Physico chemical analysis of groundwater of Ajmer city in Rajashtan, Int. J. Chem. Sci, 9 (3), 1319-1333, 2011.

[4] Hill A.R., Nitrate distribution in the groundwater of the Alliston region of Ontario, Canada, Groundwater, 20(6), pp. 696-702, 1982.

[5] Zaporozec A., Nitrate concentration under irrigated agriculture, Env. Geol. 15, pp. 35-38, 1983.

[6] Flipse W.J., Katz B.G., Lineter J.B. and Markel R., Sources of nitrate in groundwater, Central long island, New York, Groundwater, 22(4), 418426, 1984.

[7] Andersen L.J. and Kristinasen H., Nitrate in ground water and surface water related to land use in the Karup Basin, Denmark, Env. Geol, 5 (4), 207-212, 1984.

[8] Pawar N.J. and Shaikh I.J. Nitrate pollution of groundwater from shallow basaltic aquifers, Deccan Trap Hydrologic Province, India, Env., Geol, 25, 197-204, 1995.

[9] Datta P.S., Deb D.L. and Tyagi S.K., Assessment of ground water contamination from fertilizers in the Delhi area based on ${ }^{18} \mathrm{O}, \mathrm{NO}_{3}$ and $\mathrm{K}^{+}$ composition, J. of Contaminant Hydrology, 27 (3-4), 249-262 (1997).

[10] Agostiono V.D., Greene E.A., Pasorella G. and Vurro M., Spatial and Temporal study of nitrate concentration in groundwater by means of core gionalisation, Env. Geol, 36, 285-295 (1998).

[11] Jain V.K., Biofertilizers for sustainable Agriculture, Oxford Book Company, Jaipur, 2009. 
[12] APHA, AWWA and WPCF, Standard methods for the examination of water and waste water, $19^{\text {th }}$ Edition, American Public Health Association (1995).

[13] Indian Standard - Drinking Water - Specification IS 1050-1991 (Reaffirmed 2009).

[14] WHO, Sodium, chlorides and conductivity in drinking water: Report on a WHO working Group, Copenhegan, Euro Reports and Studies No.2 (1979).

[15] Hem J.D., Study and interpretation of chemical characteristics of natural water, U.S. Geol. Surv. Water supply paper No. 2254 (1991).

[16] Deshmukh K.K., The Chemistry of Groundwater in Sangamner Area with Regard To Their Suitability for Drinking Purposes, Rasayan J. Chem, 4 (4), 770-779, 2011.

[17] Ward M.H., De Kok T.M., Levallios P., Brender J., Gulis G., Nolan B.T., Vender Slice J, Drinking water nitrate and health - Recent findings and research needs, Environment Health Perspect, 113, 1607-1614, 2005.

[18] Forman D., Al-Dabbagh S., and Doll R., Nitrates, nitrites and gastric cancer in Great Britain, Nature, 313, 620-625 (1985). 